University of Nebraska - Lincoln

DigitalCommons@University of Nebraska - Lincoln

2006

\title{
The Importance of Vertical and Shared Leadership within New Venture Top Management Teams: Implications for the Performance of Startups
}

\author{
Michael D. Ensley \\ Rensselaer Polytechnic Institute, enslem@rpi.edu \\ Keith M. Hmieleski \\ Texas Christian University, k.hmieleski@tcu.edu \\ Craig L. Pearce \\ University of Nebraska - Lincoln, cpearce2@unl.edu
}

Follow this and additional works at: https://digitalcommons.unl.edu/managementfacpub

Part of the Management Sciences and Quantitative Methods Commons

Ensley, Michael D.; Hmieleski, Keith M.; and Pearce, Craig L., "The Importance of Vertical and Shared Leadership within New Venture Top Management Teams: Implications for the Performance of Startups" (2006). Management Department Faculty Publications. 71.

https://digitalcommons.unl.edu/managementfacpub/71

This Article is brought to you for free and open access by the Management Department at DigitalCommons@University of Nebraska - Lincoln. It has been accepted for inclusion in Management Department Faculty Publications by an authorized administrator of DigitalCommons@University of Nebraska - Lincoln. 
Published in The Leadership Quarterly 17:3 (June 2006; special issue on “Leadership in

Team-Based Organizations"), pp. 217-231; doi:10.1016/j.leaqua.2006.02.002

Copyright (c) 2006 Elsevier Inc. Used by permission.

Published online March 6, 2006.

\title{
The Importance of Vertical and Shared Leadership within New Venture Top Management Teams: Implications for the Performance of Startups
}

\author{
Michael D. Ensley, ${ }^{1}$ Keith M. Hmieleski, ${ }^{2}$ and Craig L. Pearce ${ }^{3}$ \\ 1. Rensselaer Polytechnic Institute, Lally School of Management and Technology, \\ Troy, NY 12180-3590, USA; enslem@rpi.edu \\ 2. Texas Christian University, M. J. Neeley School of Business, \\ Fort Worth, TX 76129, USA; k.hmieleski@tcu.edu \\ 3. Claremont Graduate University, Peter F. Drucker and Masatoshi Ito Graduate School \\ of Management, Claremont, CA 91711, USA; Craig.L.Pearce@gmail.com \\ Names of authors are in alphabetical order to indicate equal contribution. \\ Corresponding author - C. L. Pearce
}

\begin{abstract}
The current study investigated the relative influence of vertical versus shared leadership within new venture top management teams on the performance of startups using two different samples. Vertical leadership stems from an appointed or formal leader of a team (e.g., the CEO), whereas shared leadership is a form of distributed leadership stemming from within a team. Transformational, transactional, empowering, and directive dimensions of both vertical and shared leadership were examined. New venture performance was considered in terms of revenue growth and employee growth. The first sample was comprised of 66 top management teams of firms drawn from Inc. Magazine's annual list of America's 500 fastest growing startups. The seconded sample consisted of 154 top management teams of startups randomly drawn from Dun and Bradstreet, which compiles the most extensive database available for identifying relatively young American-based ventures. Both vertical and shared leadership were found to be highly significant predictors of new venture performance. Further, hierarchical regression analysis found the shared leadership variables to account for a significant amount of variance in new venture performance beyond the vertical leadership variables. These results were consistent across both samples, thus providing robust evidence for the value of shared leadership, in addition to the more traditional concept of vertical leadership.
\end{abstract}

Keywords: vertical leadership, shared leadership, startups, management, new venture

\section{Introduction}

During the last several decades, researchers have become increasingly less accepting of the notion that leadership within organizations stems only from singular individuals (e.g., CEOs) in a top-down, hierarchical process. Alternatives to this view began to emerge and become popularized through the writings of Bass (1985), Burns (1978), 
Greenleaf (1977), Lawler (1986), McGregor (1960), and Vroom and Yetton (1973). McGregor (1960), in his description of Theory Y, argued that most workers are inherently honest and intrinsically motivated to do what is right for the organization. As such, workers can be trusted to handle responsibilities that would otherwise be shouldered only by top management. Vroom \& Yetton (1973) built on the work of McGregor (1960) to develop a model of how and when leaders should involve their followers in decision-making processes. Greenleaf (1977) described the importance of "servant leadership", which involves understanding followers' needs and aspirations and helping them to fulfill their desires in ways that are ethical and socially responsible. Perhaps most importantly, he suggested that servant leaders could emerge from any level within an organization and are often not formally recognized as leaders - with their true value to the group frequently not being realized until they are gone, when the direction of the group has become noticeably less certain. To this end, Greenleaf spawned the idea that leaders need not be assigned, designated or even recognized in order to have great impact. Burns (1978) was the first to describe transformational leadership, defined as the process through which leaders appeal to the ideals and morals of their followers to inspire them to reach their highest levels of achievement and to take ownership in the goals of the group. His work further highlighted the importance for followers to become involved in shaping the goals of the group and becoming enriched in their work. Bass (1985) expanded the work of Burns, further developing the concept of transformational leadership and placing its importance more squarely into the context of organizations. Lawler (1986) further built on this energy to fuel the movement toward high-involvement management, which sought to flatten the hierarchical structure within organizations and allow workers to have added input into the design of their work and the direction of the organization.

While these classic works have effectively espoused the importance of including followers in important decision-making processes, the focus of these theoretical frameworks remains on the juxtaposition of individual actors who are categorized as either leaders or followers. As such, these views remain yoked to the concept of "leader as commander," which became the dominant leadership paradigm during the scientific management movement (Gilbreth \& Gilbreth, 1924; Taylor, 1911). This has left an unsettled feeling among many who have recognized that high-performing groups often do not have formal leadership structures (Manz \& Sims, 1984). Instead, leadership within high-performing groups is often distributed such that those with relevant knowledge, skills or abilities offer their views within specific situations, which are then digested and acted upon by the group as a unit. Kiefer \& Senge (1999) describe firms operating in this way as metanoic organizations. Within such firms conversations are not dominated by individuals designated as leaders, but rather flow in rhythm to those possessing the most relevant knowledge to offer regarding the problem or opportunity of the moment. This emerging view of leadership has led to what has become known as distributed (Gronn, 2005) or shared leadership (Pearce \& Conger, 2003) - note that these terms are used somewhat interchangeably in the literature.

Pearce (2004, p. 48) defines shared leadership as a simultaneous, ongoing, mutual influence process within a team that is characterized by "serial emergence" of official as well as unofficial leaders. Although the need for shared leadership was explicitly described many decades ago (e.g., Follett, 1924), the concept has failed to gain traction within the mainstream leadership literature until recently. As Kuhn (1970) has described, knowledge underlying future paradigm shifts is often recognized by many individuals well before an actual paradigm shift occurs. The incentive structure must exist to motivate enough people to make the appropriate connections and actively build momentum toward moving beyond previous ways of thinking (Burke, 1978). It appears as though the current leadership paradigm is just now beginning to expand beyond the leader as commander outlook that has long dominated the field. This, we suggest, is a result of the proliferation of self-managed work groups (Wolff, Pescosolido, \& Druskat, 2002), as well as the increased application of systems thinking (Nicholls-Nixon, 2005), complexity theories (Marion \& Uhl-Bien, 2001) and decentralized organizational designs (Balogun \& Johnson, 2004). These events have forced individuals to rethink traditional views of leadership. This is not to say that vertical leadership is the way of the past, but rather that future thinking about leadership must encompass both vertical and shared facets in order to capture a fuller view of leadership processes and outcomes (Day et al., 2004; Pearce \& Sims, 2002).

Although the concept of shared leadership has begun to emerge with increased regularity within the leadership literature, there have been, to this point, only few empirical studies on the topic (e.g., Avolio et al., 1996; Pearce, 1997; Pearce \& Sims, 2002; Pearce et al., 2004). Instead, the literature on shared leadership has predominately been focused on its theoretical development (Day et al., 2004; Gronn, 2002) and practical application (Pearce, 2004; Pearce \& Manz, 2005). The aim of the current study is to empirically examine the explanatory value in models of vertical versus shared leadership using parallel measures of each construct. Our goal in so doing is not to determine whether shared models of leadership are superior to vertical models of leadership, when it comes to predicting new 
venture performance, but rather to explore whether significant value can be realized by considering shared aspects of leadership-beyond that which is accounted for by more parsimonious models, which consider only vertical leadership. In this regard, we build upon the work of Pearce \& Sims (2002); Pearce et al. (2004), who found shared leadership to be a more useful predictor of team outcomes than vertical leadership -in change management and virtual teams, respectively. The current study seeks to determine whether the value of shared leadership can also be realized at the organizational level, thereby extending previous research on the topic. The new venture context is chosen to carry out this study due to the natural linkage between entrepreneurship and leadership (Cogliser \& Brigham, 2004; Vecchio, 2003), and the effect that team processes have been found to have on the development and growth of startups (Ensley et al., 2003; Ucbasaran et al., 2003). Further, new ventures provide an entirely different context from that which was studied in previous empirical work, thus maximizing the extent to which we can generalize about the utility of vertical and shared leadership.

We begin in the following section by discussing the important role of leadership within the new venture context. Next, we delineate differences between vertical and shared leadership. Afterward, the case is made for the value of both vertical and shared leadership within new venture top management teams. We then describe the samples and methods that are used to examine the effects of vertical and shared leadership on new venture performance. Finally, the results of our analyses are described, and their implications are discussed.

\section{Leadership within the new venture context}

For startups to come into existence, their founding top management teams need to create a vision for their firms and influence others to buy into their dreams in order to attract employees and acquire necessary resources for developing their new ventures (Baum, Locke, \& Kirkpatrick, 1998). Further, new venture top management teams need to set the initial goals and reward structures for their workers (Williamson, 2000). Simply put, in the context of new venture creation, founding teams must lead because there are no standard operating procedures or organizational structures to fall back on when creating a firm from scratch (Bryant, 2004). This distinction differentiates new venture top management teams from top management teams of larger, more established corporations which often have more well-defined goals, structures, and work processes to guide them (Ensley, Pearce, \& Hmieleski, in press). Thus, whereas there may be substitutes and/or blockers of leadership in larger and more established organizations (Kerr \& Jermier, 1978), there are, by definition, far less alternatives or impediments to leadership in new ventures.

In a similar vein, during the initial stages of the venture creation process, new venture top management teams tend to lead their startups under situations that could be characterized as "weak" rather than "strong." Strong situations are those in which there are relatively uniform expectancies regarding appropriate behavior (Mischel, 1977). In strong situations, certain behaviors are reinforced by normative expectations and incentive structures that support learning those behaviors. Weak situations, on the other hand, lack these characteristics and do not provide clear incentives, support, or normative expectations for what constitutes appropriate behavior (Mischel, 1977). It has been demonstrated that in weak situations individuals' behaviors are more clearly linked to organizational outcomes than in strong situations (Mullins \& Cummings, 1999). Thus, the leadership behavior of top management is likely to have a greater and more direct impact on firm performance in startups than in larger and more established organizations, making new ventures a particularly important context in which to examine the effects of leadership behavior.

This line of reasoning is also supported by Hambrick and colleague's work on managerial discretion, which considers the "latitude of action" top management has over their behavior. Those teams with the most latitude or discretion are thought to have the greatest potential impact on the performance of their firms (Hambrick \& Abrahamson, 1995; Hambrick \& Finkelstein, 1987). Virtually by definition, top management teams of new venture have considerably more discretion and less bureaucracy to deal with than those of larger, more established organizations. Still further, work by Kets de Vries \& Miller $(1984,1986)$ demonstrates how the individual characteristics and behavior of founding teams can become imprinted into the organizational culture of firms, which becomes institutionalized and difficult to later modify (Schein, 1997). This concept is congruent with Hambrick and Mason's (1984) theory of upper echelons, which proposes that organizations can be seen as a reflection of their top management. Taken together, various streams of research appear to support the argument that the leadership behavior of founders and their top management teams is likely to have direct and profound effects on the development and longterm sustainability of their new ventures. 
In addition, the new venture context is characterized by interdependence (Bygrave \& Minniti, 2000), creativity (Ward, 2004), and complexity (McKelvey, 2004). These three factors have been detailed by Pearce (2004) as conditions in which the benefits of shared leadership are greatest. Therefore, the clear and direct connections between shared leadership behavior and objective performance outcomes, coupled with the need for sharing leadership within the top management team, make new ventures an ideal context for studying both vertical and shared leadership. Finally, by considering vertical and shared leadership within this context, the current study follows a growing stream of work attempting to advance knowledge within both the fields of entrepreneurship and organizational behavior (Baron, 2002).

\section{Distinguishing between vertical and shared leadership}

Leadership is the process of influencing others to understand and agree about what needs to be done and how it can be done effectively, and the process of facilitating individual and collective efforts to accomplish a shared objective (Yukl, 2002). In top management teams, there are two potential sources of leadership, which are defined by "who" engages in leadership. The first source, the vertical leader, has received considerable attention and support in the literature (Gerstner \& Day, 1997; Schriesheim et al., 1994). The second source, the team, has been the focus of an emerging stream of research that views the team as a potential source of leadership (Burke et al., 2003; Gronn, 2005; Pearce \& Conger, 2003). Vertical leadership may be viewed as an influence on team processes. In contrast, shared leadership is a team process where leadership is carried out by the team as a whole, rather than solely by a single designated individual. To this end, vertical leadership is dependent upon the wisdom of an individual leader, whereas shared leadership draws from the knowledge of a collective. Further, vertical leadership takes place through a top-down influence process, whereas shared leadership flows through a collaborative process.

Here we focus on four fundamental types of leadership that team members might share-directive, transactional, transformational, and empowering (Pearce, 2004). Shared directive leadership, for example, might be expressed as peers test one another with a directive give-and-take about how to engage key stakeholders, develop strategic initiatives or how to create internal systems and structures. Similarly, shared transactional leadership might be expressed through collegial recognition of efforts and contributions or by establishing key performance metrics and distributing rewards based on those metrics. Additionally, teams might engage in shared transformational leadership through the creation of a shared strategic vision or by inspiring one another to challenge existing industry standards and norms to create break-through products or services. Finally, shared empowering leadership might be expressed in a team through peer-based support and encouragement of providing self-rewards, viewing personal obstacles as opportunities to learn or engaging in teamwork and participative goal setting with other members of the team. The following sections elaborate on the importance of both vertical and shared leadership within the new venture context.

\section{The case for vertical leadership}

Research has shown that, although new ventures are often formed by founding teams, one individual often emerges as the principal leader (Ensley, Carland, \& Carland, 2000). The inspiration and vision of this person have been often cited as the driving force behind the performance of new ventures, highlighting the importance of transformational leadership behavior within startups (Baum et al., 1998). In addition, the importance for the lead entrepreneur to effectively display empowering leadership behaviors, such as promoting opportunity thinking and participative goal setting amongst his/her followers, has also been emphasized within the entrepreneurship literature (McGrath \& MacMillan, 2000). It has, in fact, become the majority held view within the entrepreneurship literature that transformational and empowering types of vertical leadership are essential for leading new ventures toward high growth (Covin \& Slevin, 2002, 2004; Gupta et al., 2004; Ireland et al., 2003). This position is based in the fact that new venture top management team leaders must gain extraordinary commitment and focus from their workers in order to overcome the liability of newness that they face and to compete against more well-established and resource-rich incumbents (Bryant, 2004; Stinchcombe, 1965). On the other hand, the case has also been made that transactional and directive behaviors are important forms of vertical leadership within new ventures (Muczyk \& Reimann, 1987). This view stems from the need for clear goals and reward contingencies to be set during the initial stages of the new venture creation process.

There are most likely circumstances whereby each of the directive, transactional, transformational and empowering facets of vertical leadership differ in regard to their relative effects on new venture performance. For example, 
a study by Ensley et al. (in press) found transformational top management team leader behavior to have its most positive effects on new venture performance under dynamic environmental conditions, whereas transactional leadership behavior was found to be most effective within more stable environmental conditions. As such, we cast a wide net to suggest that vertical leadership in general will be positively related to new venture performance.

H1. Vertical leadership in new venture top management teams will be positively related to new venture performance, such that the more directive, transactional, transformational and empowering the top leader of the firm, the higher the growth rate of the firm will be.

\section{The case for shared leadership}

The entrepreneurship literature has long been preoccupied by the concept of the lone entrepreneur whoagainst all odds - creates a new venture and single handedly takes down larger, more established incumbents, in a David versus Goliath fashion. This fascination with the individual entrepreneur as the nexus of the venture creation process has led entrepreneurship researchers on an unproductive quest to identify the optimal traits of individual entrepreneurs (Gartner, 1989) and has placed an overemphasis on vertical leadership within the new ventures context (Gupta et al., 2004), while relatively neglecting founding teams as an area of research. This is unfortunate considering that relying solely on vertical leadership in top management teams would seem "to ignore leadership dynamics within a group context" (Barry, 1991, p. 32).

Despite the initial lack of attention directed toward new venture top management teams, research in this area has begun to emerge (Ucbasaran et al., 2003). A particularly relevant example is Ensley \& Pearce's (2001) work linking shared cognition to new venture performance. These authors suggest that new venture top management team performance is highly dependent on the top management team process of building a unified vision of the firm's mission. So doing allows team members to share dissenting views, yet remain tied to a singular focus without allowing disagreement to pull the team into a downward spiral of conflict. Further, Ensley et al. (2003) discuss the critical role that shared leadership plays in facilitating the process of developing shared strategic cognition within new venture top management teams.

Work on shared forms of leadership within other types of organizations is also likely to inform the value of shared leadership within the new venture context. For example, emerging work on self-managing work teams suggests that group self-leadership (Manz \& Sims, 1993), team self-leadership (Stewart \& Barrick, 2000), distributed leadership (Day et al., 2004; Gronn, 2005) or shared leadership (Hooker \& Csikszentmihalyai, 2003; Katzenbbach \& Smith, 1993; Shamir \& Lapidot, 2003; Pearce, 1997; Pearce \& Sims, 2002; Pearce et al., 2004) is associated with more effective teams. For example, Katzenbbach \& Smith's (1993) study demonstrated that high-performance teams actively engaged in shared leadership much more than other teams. Further, Avolio et al. (1996), in a study of undergraduate teams, found shared leadership to be significantly related to self-ratings of effectiveness. In a longitudinal study of change management teams, Pearce \& Sims (2002) found shared leadership to be a more useful predictor, than vertical leadership, of manager, customer and team self-ratings of effectiveness. Pearce et al. (2004), in a study of virtual teams, also found shared leadership to be a more important predictor, than vertical leadership, of self-rated problem solving quality and effectiveness. Finally, qualitative studies by Hooker \& Csikszentmihalyai (2003), in research and development laboratories and Shamir \& Lapidot (2003), in the military, suggest that shared leadership is related to the effectiveness of teams. Accordingly, there appears to be no reason why shared leadership within new venture top management teams will not translate into equally high performance for startups. To this end, we suggest that shared leadership will be positively related to new venture performance, and that it will account for additional variance in new venture performance above and beyond that which is explained by vertical leadership.

H2. Shared leadership in new venture top management teams will be positively related to new venture performance, such that the more directive, transactional, transformational and empowering the top management team members of the firm, the higher the growth rate of the firm will be.

H3. Shared leadership within the new venture top management team will account for a significant amount of variance in new venture performance above and beyond that which is accounted for by the vertical leadership of the new venture top management team leader. 


\section{Methodology}

\subsection{Sample for study one}

The sample for study one was drawn from the annual Inc. 500 list of America's fastest growing startups. Given our focus on the leadership of new ventures, we gathered data from the members of the top management teams of these firms. Because the Inc. 500 typically consists of small firms, in relatively early stages of their development, it seemed an appropriate population for study. Firms such as these are still highly dependent upon the vision and direction of their top management teams. Each of the 1142 officers of the 500 firms received a personalized letter and individually numbered questionnaire. Individual names and addresses for the top management team members were obtained from the Dun and Bradstreet Market Identifiers database. Of the 1142 questionnaires mailed, a total of 258 responses were returned from 164 firms. However, after eliminating firms that were no longer in existence, firms from which we received responses from less than half of the top management team members, managers who were not active on the top management team, and managers who provided incomplete responses, our sample was reduced to 168 managers from 66 firms, a response rate of $17.6 \%$. Various sources of non-response bias were assessed. $T$-tests on six variables including strategic orientation, revenue, firm age, size, growth rate, and profit level were conducted. All yielded non-significant results.

Of the 168 managers, 93\% were male and the average age was 37.2 years. Seventy-four percent were founders and $82 \%$ held at least $10 \%$ equity in their firm. Ninety percent considered themselves entrepreneurs and $34 \%$ had been previously involved in other new ventures. During the previous 5 years, revenue growth for these firms ranged from $634 \%$ to $10,432 \%$, and averaged $1623 \%$. A total of 38 industries were represented and the age of the firms ranged from 5 to 9 years, with an average of 6.8. Top management team size averaged 2.55 and ranged from two to six.

\subsection{Sample for study two}

The second sample was drawn from the Dun and Bradstreet Market Identifiers Database. Dun and Bradstreet compiles what is considered to be the most exhaustive database of young firms founded in the United States. Thus, a sample of firms drawn from their database-although not a completely random sample-is arguably as close to a random sample of startups as can be feasibly drawn. Participants had to meet the same requirements for inclusion as in study one. Each of 1242 officers from the 500 sampled startups was mailed a personalized letter and individually numbered questionnaire. A total of 657 responses were returned from 231 firms. After eliminating firms from which we received responses from less than half of the top management team members, managers who were not active on the top management team, and participants who provided incomplete responses, our sample was reduced to 417 executives from 154 firms, a response rate of $33.5 \%$. Sources of response bias were checked following the same techniques and variables as for study one, and all yielded non-significant results.

Of the 417 team members retained, approximately $88 \%$ were male and the average age was 44.2 years. Sixtyeight percent were founders and $71 \%$ held at least $10 \%$ equity in their firm. Nearly $90 \%$ considered themselves entrepreneurs and $47 \%$ had been involved in new ventures previously. Just over $45 \%$ reported their highest degree as a bachelor's degree, $17 \%$ held master's degrees and $5 \%$ held doctorates. Majors included engineering, accounting, business, biology, chemistry, history, political science, and others (less than 5\%). During the 3 years prior to the data collection, the average rate of growth for these firms was $78 \%$ per year and ranged from a low of $21 \%$ to a high of $114 \%$. A total of 72 industries were represented and the average firm age was 4.3 years. Average team size was 2.71 .

\subsection{Statistical approach}

For both samples, hierarchical regression analysis was used test the hypotheses. Hypothesis 1 was tested by entering the control variables in step one and the vertical leadership variables in step two. Hypothesis 2 was tested by entering the control variables in step one and the shared leadership variables in step two. Hypothesis 3 was tested by entering the control variables in step one, the vertical leadership variables in step two, and the shared leadership variables in step 3. 


\subsection{Measures}

The first step in developing the leadership behavior survey used in the current research project was to begin with a questionnaire designed by Cox (1994). Earlier versions of the Cox instrument are reported in Scully et al. (1994) and Ball (1991). A full-scale validation study of the measures was conducted by Pearce et al. (2003) and found the instrument to have strong psychometric properties. Items were slightly modified to reflect the unique aspect of the current project. For example, phrases such as "team leader" used to measure vertical leadership were changed to "team members" to measure shared leadership. Therefore, the questionnaire was structured to allow subjects to respond to the same question both in reference to vertical and to shared leadership. A similar "double response format" has been used successfully in previous research to measure leadership from an external source versus an internal source (cf. Manz \& Sims, 1987) and to measure vertical versus shared leadership (Pearce, 1997; Pearce \& Sims, 2002; Pearce et al., 2004).

We examined three sub-dimensions of directive leadership, two sub-dimensions of transactional leadership, four sub-dimensions of transformational leadership, and four sub-dimensions of empowering leadership. All subdimensions consisted of three items. These dimensions were measured both as they apply to the appointed team leader and to the overall executive team. For directive leadership, the sub-dimensions included instruction and command (e.g., "When it comes to my work, my team leader (members) gives (give) me instructions on how to carry it out"), assigned goals (e.g., "My team leader (members) establishes (establish) my performance goals"), and contingent reprimand (e.g., "My team leader (members) lets (let) me know about it when I perform poorly"). For transactional leadership the sub-dimensions were contingent personal reward (e.g., "My team leader (members) gives (give) me positive feedback when I perform well"), and contingent material reward (e.g., "My team leader (members) will recommend that I am compensated more if I perform well"). For transformational leadership the sub-dimensions comprised stimulation and inspiration (e.g., "My team leader (members) shows (show) enthusiasm for my efforts"), performance expectations (e.g., "My team leader (members) expects (expect) me to perform at my highest level"), vision ("e.g., My team leader (members) provides (provide) a clear vision of where our team is going"), challenge to the status quo (e.g., "My team leader (members) isn't (aren't) afraid to 'break the mold' to find different ways of doing things"). For empowering leadership, the sub-dimensions included encourages opportunity thinking (e.g., "My team leader (members) advises (advise) me to look for opportunities contained in the problems I face"), encourages self-reward ("My team leader (members) encourages (encourage) me to treat myself to something I enjoy when I do a task especially well"), participative goal setting (e.g., "My team leader (members) and I work together to decide what my performance goals should be"), and encourages teamwork (e.g., "My team leader (members) encourages (encourage) me to work together with other individuals who are part of the team"). Cronbach coefficient alphas for each of the leadership dimensions studied can be found across the diagonals of Table 1 and Table 2. In each case, the alphas were above the 0.70 minimum level of internal consistence for use in research (Nunnally \& Bernstein, 1996).

For both studies, we formed study variables by summing the mean scores from each of the sub-dimensions to derive a single indicator of each of four types of vertical and shared leadership styles for each team and we subsequently mean centered each of these variables for hypothesis testing. For the directive, transactional, transformational, and empowering sub-dimensions, the level of within-team agreement was assessed before the individual measures were combined to form study variables (Amason, 1996; Scully et al., 1994). We used the reliability within groups on $j$-number of items procedure, known as the $r_{W G(J)}$ (James, Demaree, \& Wolf, 1993). The $r_{W G(J)}$ produces a value between 0 and 1.0, with scores above 0.70 denoting acceptable agreement. For the sub-dimensions for each of the measured leadership behaviors, $r_{W G(I) s}$ ranged from 0.72 to 0.88 . Thus, there was acceptable agreement within the teams on the use of each of the measured vertical and shared leadership behaviors.

To further examine the psychometric properties of the study variables, we also examined within and between group variance. Using a one-way ANOVA, we tested and found significant variance between the executive teams on the use of shared and vertical leadership (for study one: $F=4.61, p<0.01$; for study two: $F=11.62, p<0.01$ ). Thus, there appears to be substantial variance between the teams and therefore a basis for testing our hypotheses. The next section discusses the criterion variables used in the studies.

\subsubsection{Criterion variables}

Growth is often cited as an objective of new ventures (Brush \& Vanderwerf, 1992). In this vein, we used average annual revenue growth as one measure of performance. The second performance variable used was average annual 
growth rate in the number of workers employed by the firm. The performance data for study one were acquired from Inc. Magazine, which reported 5-year revenue and employee growth rates; while performance data for study 2 were provided by Dun and Bradstreet, which reported 3-year revenue and employee growth rates.

An index of new venture growth was formed using firm revenue growth and employee growth as objective performance indicators (McGuire et al., 1986; Keats \& Hitt, 1988). We averaged the two growth measures as a single index of growth. We did this only after conducting separate regression analyses of the leadership variables on revenue growth and employee growth, where we found consistent results. This index allows for a more parsimonious view of the outcomes.

Control variables for both samples included firm age, firm size, and top management team size. Firm age was measured as the number of years since the firm had been established. Firm size was measured using the natural log of yearly revenues. Top management team size was measured using the number of managers who met our criteria for inclusion in the study.

Table 1. Means, standard deviations, and correlations of study variables

\begin{tabular}{|c|c|c|c|c|c|c|c|c|c|c|c|c|c|}
\hline \multicolumn{14}{|l|}{ Inc. 500 sample } \\
\hline 1. Firm age & 6.80 & 1.40 & & & & & & & & & & & \\
\hline 2. Revenues (Log) & 3.14 & 0.53 & $0.27^{*}$ & & & & & & & & & & \\
\hline 3. Team size & 2.55 & 1.48 & 0.08 & 0.05 & & & & & & & & & \\
\hline 4. V. directive & 2.45 & 0.80 & 0.01 & $-0.11^{* *}$ & 0.01 & $(0.81)$ & & & & & & & \\
\hline 7. V. empowering & 2.94 & 0.84 & 0.04 & 0.07 & 0.07 & $0.15^{*}$ & $0.17^{* *}$ & $0.51^{*}$ & $(0.89)$ & & & & \\
\hline 8. S. directive & 2.37 & 0.77 & 0.02 & 0.09 & $0.11^{*}$ & $0.29 * *$ & $0.14^{*}$ & $0.13^{* *}$ & $0.27^{* *}$ & $(0.73)$ & & & \\
\hline 9. S. transactional & 3.12 & 1.08 & 0.06 & $0.14^{* *}$ & 0.07 & $0.23^{* *}$ & 0.19 ** & $0.12^{* *}$ & $0.25^{* *}$ & $0.44^{* *}$ & $(0.77)$ & & \\
\hline 10. S. transformational & 3.27 & 0.99 & 0.09 & $0.17^{*}$ & 0.09 & $0.11^{*}$ & $0.21^{* *}$ & $0.61^{* *}$ & $0.36^{* *}$ & $0.56^{* *}$ & $0.47^{* *}$ & $(0.79)$ & \\
\hline 11. S. empowering & 3.36 & 1.34 & 0.04 & 0.09 & 0.10 & $0.16^{*}$ & $0.14^{*}$ & $0.47^{* *}$ & $0.71^{* *}$ & $0.41^{* *}$ & $0.43^{* *}$ & $0.67^{* *}$ & $(0.75)$ \\
\hline
\end{tabular}

$\mathrm{V}=$ Vertical, $\mathrm{S}=$ Shared.Note: Cronbach coefficient alphas for the leadership variables are listed in parentheses along the diagonal.

${ }^{*} p<.05$

$* * p<.01$

Table 2. Means, standard deviations, and correlations of study variables

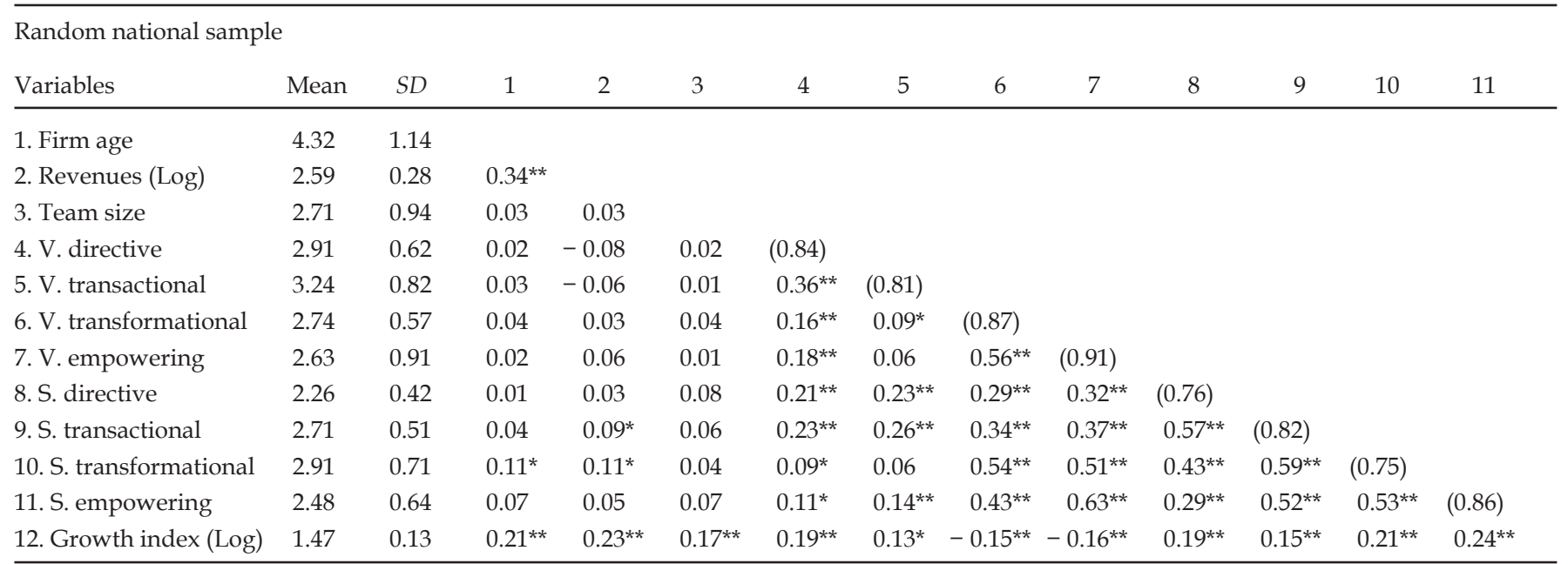

$\mathrm{V}=$ Vertical, $\mathrm{S}=$ Shared.Note: Cronbach coefficient alphas for the leadership variables are listed in parentheses along the diagonal.

${ }^{*} p<.05$

${ }^{* *} p<.01$ 


\section{Results}

The means, standard deviations and correlations for all variables examined in studies 1 and 2 can be found in Table 1 and Table 2, respectively. In addition, the hierarchical regression results used to test the hypotheses can be found in Table 3 and Table 4.

Hypothesis 1 stated that vertical leadership in new venture top management teams will be positively related to new venture performance, such that the more directive, transactional, transformational and empowering the top leader of the firm, the higher the growth rate of the firm will be. The change in $R^{2}$ was $18 \%(p<0.01)$ in the Inc. 500 sample and $15 \%(p<0.01)$ in the random national sample, beyond the control variables, suggesting support for Hypothesis 1. The findings from both regression analyses, however, do not fully support this conclusion, when we examine the beta weights of the study variables. The findings in study one demonstrate that while vertical directive leadership $(\beta=0.29, \mathrm{p} .<0.01)$ and vertical transactional leadership $(\beta=0.24, p<0.05)$ were positively related to firm growth, vertical transformational leadership $(\beta=-.32, p<0.01)$ and vertical empowering leadership $(\beta=-.34, p<0.01)$ were negatively related to firm growth. These findings were found to be similar in study two, where vertical directive leadership $(\beta=0.21, p<0.01)$ and vertical transactional leadership $(\beta=0.24$, $p<0.05)$ were positively related to firm growth, while vertical transformational leadership $(\beta=-.31, p<0.01)$ and vertical empowering leadership $(\beta=-.26, p<0.01)$ were negatively related to firm growth. Therefore, Hypothesis 1 is only partly supported.

Hypothesis 2 stated that shared leadership in new venture top management teams will be positively related to new venture performance, such that the more directive, transactional, transformational and empowering the top management team members of the firm, the higher the growth rate of the firm will be. The change in $R^{2}$ was $28 \%(p<0.01)$ in the Inc. 500 sample and $30 \%(p<0.01)$ in the random national sample, beyond the control variables, suggesting support for Hypothesis 2 . For study one, shared directive leadership $(\beta=0.56, p<0.01)$, shared transactional leadership $(\beta=0.31, p<0.05)$, shared transformational leadership $(\beta=0.46, p<0.01)$ and shared empowering leadership $(\beta=0.38, p<0.01)$ all had positive and significant beta coefficients. The results from study two were similar, where shared directive leadership $(\beta=0.65, p<0.01)$, shared transactional leadership $(\beta=0.38, p<0.01)$, shared transformational leadership $(\beta=0.49, p<0.01)$ and shared empowering leadership $(\beta=0.37, p<0.01)$ all had positive and significant beta coefficients as well. Accordingly, support for Hypothesis 2 is found.

Table 3. Vertical and shared leadership in startup executive teams

Inc. 500 sample

Variables

Growth index

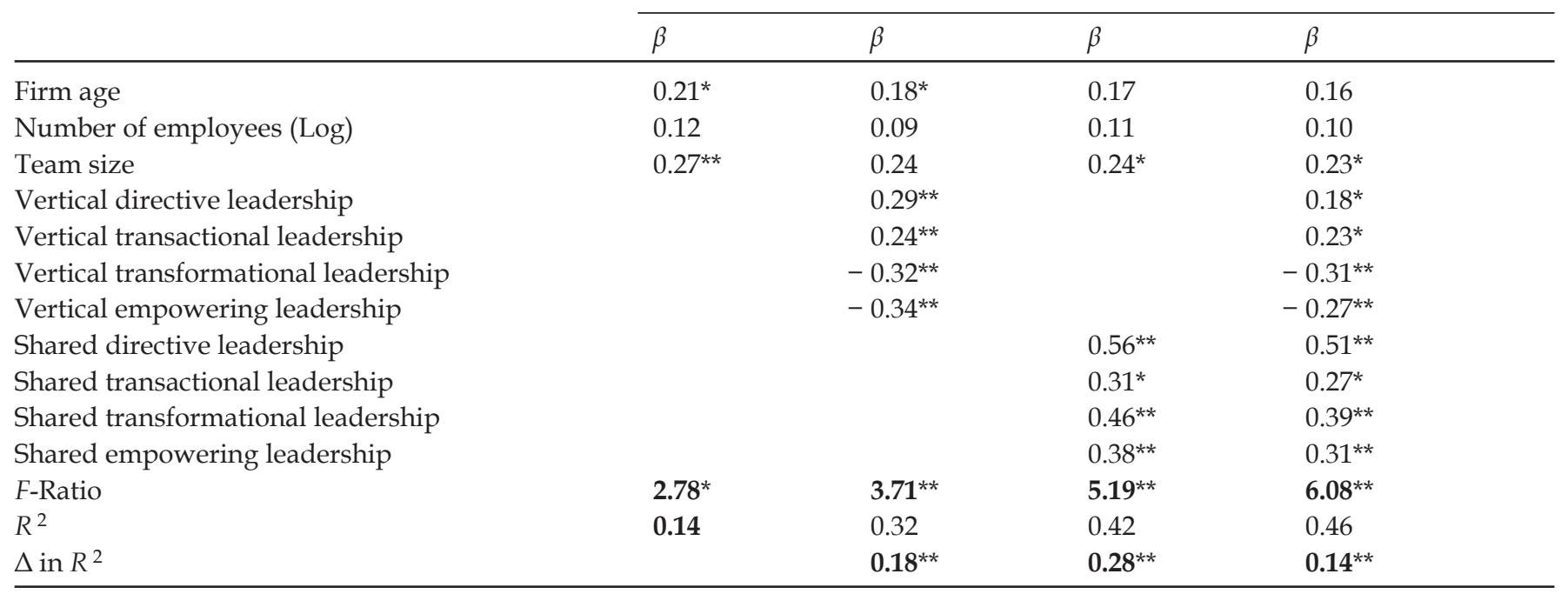

$N=66$ New Venture Executive Teams

${ }^{*} p<.05$

${ }^{* *} p<.01$ 
Hypothesis 3 stated that shared leadership within the new venture top management team will account for a significant amount of variance in new venture performance above and beyond that which is accounted for by vertical leadership of the new venture top management team leader. For both studies, the shared leadership variables were found to account for a significant amount of variance in new venture growth beyond that which was accounted for by the control variables and vertical leadership variables (see Table 3 and Table 4). Specifically, shared leadership accounted for an additional $14 \%(p<0.01)$ of the variance in new venture performance for the Inc. 500 sample and $20 \%(p<0.01)$ of the variance in new venture performance for the random national sample, beyond the control variables and the parallel dimensions of vertical leadership. Therefore, Hypothesis 3 is supported.

\section{Discussion}

Teams and team leadership have become an increasingly important area of research (Day, 2000; Day et al., 2004; Forsyth, 1999; Swezey \& Salas, 1992). As Hollenbeck, Ilgen, \& Sego (1994) observed over a decade ago, "there is a strong need for a better understanding of team functioning and team leadership in a wide variety of contexts." Nonetheless, as the study of leadership dynamics in top management teams presents considerable challenge, there is a notable dearth of studies in the area (Zaccaro, Rittman, \& Marks, 2001). In response, we examined both vertical and shared leadership within new venture top management teams, which we argued to be a context in which the effects of leadership behavior on performance are likely to be particularly meaningful and robust. As anticipated, new ventures were found to present a relatively transparent context for capturing the effects of both vertical and shared leadership behaviors. Both sources of leadership were found to be important predictors of new venture performance. Shared leadership was, however, found to be a particularly efficacious predictor of new venture performance, which is consistent with prior research on shared leadership within other contexts (e.g., Pearce \& Sims, 2002; Pearce et al., 2004). As such, our results extend previous findings by demonstrating the value of shared leadership within a different context than has been previously examined, and by considering outcomes beyond team effectiveness, demonstrating the effects of shared leadership on important organizational performance outcomes.

There are several reasons why we feel particularly confident in the validity of our findings. First, this research utilized multiple samples. Second, independent and dependent measures were collected from different sources, thereby enhancing the ability to interpret the results. Third, the range of leader behaviors examined was extensive, as we examined multiple facets of directive, transactional, transformational and empowering leadership in their parallel vertical and shared forms. In the following sections we discuss our results and their implications in more detail.

Table 4. Vertical and shared leadership in startup executive teams

\begin{tabular}{|c|c|c|c|c|}
\hline \multicolumn{5}{|l|}{ Random national sample } \\
\hline \multirow[t]{2}{*}{ Variables } & \multicolumn{4}{|c|}{ Growth index } \\
\hline & $\beta$ & $\beta$ & $\beta$ & $\beta$ \\
\hline Firm age & $0.29^{* *}$ & $0.24^{*}$ & 0.23 & $0.21^{*}$ \\
\hline Number of employees (Log) & 0.11 & 0.07 & 0.07 & 0.06 \\
\hline Team size & $0.27^{* *}$ & $0.31^{* *}$ & $0.29^{*}$ & $0.27^{* *}$ \\
\hline Vertical directive leadership & & $0.21^{*}$ & & 0.11 \\
\hline Vertical transactional leadership & & $0.24 * *$ & & 0.13 \\
\hline Vertical transformational leadership & & $-0.31^{* *}$ & & $-0.26^{* *}$ \\
\hline Vertical empowering leadership & & $-0.26^{* *}$ & & $-0.29^{* *}$ \\
\hline Shared directive leadership & & & $0.65^{* *}$ & $0.61^{* *}$ \\
\hline Shared transactional leadership & & & $0.38^{* *}$ & $0.34^{* *}$ \\
\hline Shared transformational leadership & & & $0.49 * *$ & $0.44^{* *}$ \\
\hline Shared empowering leadership & & & $0.37^{* *}$ & $0.33^{* *}$ \\
\hline F-Ratio & $2.73^{\star}$ & $4.08^{* *}$ & $5.73^{* *}$ & $7.31^{\star *}$ \\
\hline$R^{2}$ & 0.17 & 0.32 & 0.47 & 0.52 \\
\hline$\Delta$ in $R^{2}$ & & $0.15^{\star *}$ & 0.30 & $0.20^{* *}$ \\
\hline
\end{tabular}

$N=213$ New Venture Executive Teams

${ }^{*} p<.05$

$* * p<.01$ 


\subsection{Divergent results for transformational and empowering leadership}

Of particular interest in the current research are the divergent results for vertical and shared leadership concerning transformational and empowering aspects of leadership. While shared transformational and empowering leadership had positive effects on performance, vertical transformational and empowering leadership had negative effects. We were initially perplexed by these findings, as they are contrary to the majority of findings on transformational and empowering leadership (e.g., Pearce \& Sims, 2002). Upon deeper reflection, however, we might deem these findings to be attributed to the unique nature of the new venture context. For example, the members of these teams are clearly highly motivated regarding the performance of the venture. As such, attempts to inspire and empower them from above with transformational and empowering leadership may be viewed as redundant and unnecessary. Team members may even perceive this type of leadership as an overt attempt at psychological manipulation. There is also a substantial body of literature demonstrating the need for new ventures to have extreme focus on specific goals (Dean et al., 1998; Winborg \& Landstrom, 2001). In this regard, vertical transformational and empowering leadership could potentially distract the team and create unnecessary ambiguity, whereas shared transformational and empowering leadership my result in positive effects by helping the teams sort through strategic issues as a collective. Accordingly, we might speculate that these explanations may account for the negative relationship between vertical transformational and empowering leadership and firm performance.

On the other hand, we might speculate that the negative effects of vertical transformational and empowering leadership are only identifiable beyond some threshold level of each type of leadership and that both types of leadership are necessary, but only in limited quantities. Alternatively, this finding may simply represent a statistical artifact. Nonetheless, our findings are an indication that knowledge learned through studies of leadership within large, established organizations might not map as clearly onto the new venture context as others have previously suggested (Vecchio, 2003). To this end, there appears to be a need for further empirical research on leadership within the new venture context.

\subsection{Leadership and the stage of venture development}

It may be that the relative importance of vertical versus shared leadership is dependent on the stage in the development or evolution of the organization. For example, vertical leadership may be especially important during the pre-formation stage of the new venture. It is typically a single individual who initially recognizes an entrepreneurial opportunity and decides to follow through to exploit that opportunity by forming a new venture. This individual must set out to form the initial vision and goals for the nascent firms, and effectively influence others to buy into his/her vision and join him/her as partners, employees, investors, suppliers, buyers and so forth. Further, during times of dramatic change within an organization, vertical leadership may be especially critical. For example, vertical forms of leadership have been shown to be particularly effective in accomplishing large-scale change within organizations (Dunphy \& Stace, 1993).

On the other hand, once the ball gets rolling and the startup begins to grow, it is not feasible for a single individual to take on all leadership responsibilities for the various duties that must be performed. From the results of the current study, it appears that shared leadership within a skilled and diverse top management team is likely to produce superior outcomes, which builds on previous qualitative work (e.g., Gronn, 1999; Hooker \& Csikszentmihalyai, 2003; Shamir \& Lapidot, 2003; Pearce, 2004) and quantitative work (e.g., Avolio et al., 1996; Pearce \& Sims, 2002; Pearce et al., 2004) that has shown the efficacy of shared leadership in a wide variety of contexts.

In this vein, our results may have produced findings indicating the saliency of shared leadership, in terms of its effects on firm performance, simply due to the fact that the firms sampled were in the growth stage of their initial development-when perhaps shared leadership is especially critical. Over the lifespan of a firm, however, optimal organizational leadership probably involves a continuous ebb and flow between vertical and shared leadership. In fact, many researchers have suggested that the ideal mode of leadership in organizations is likely to depend on the stage in the life cycle of the organization (Baglia \& Hunt, 1988; Miller \& Friesen, 1984; Quinn \& Cameron, 1983; Smith \& Miner, 1983; Smith et al., 1985). Therefore, future research might advance our knowledge of vertical and shared leadership through longitudinal study across various stages of firms' development. 


\subsection{Implications for leadership development}

Most leadership development efforts tend to be geared toward transactional and transformational leadership and focus narrowly on formally designated leaders or those being groomed to occupy such positions (Conger, 1999; Day, 2000). Our results clearly indicate a need to broaden the behavioral range of leadership development. Leadership typologies offer a guiding framework for implementing leadership development efforts: "The behavioral richness of the typologies guiding leadership development define and, in some cases, limit the leadership behaviors supported by curriculum and development strategy" (Cox, Pearce, \& Sims, 2003, p. 162). To develop leaders with a more complete array of behavioral options, we recommend expanding beyond the limits of today's dominant transactional-transformational leadership typology, to include the once popular directive and newly emerging empowering types of leadership.

Moreover, when we think of leadership, we typically think of one person projecting influence downward on followers. Nonetheless, Ensley et al. (2003) specifically articulated an important role for shared leadership in entrepreneurial top management teams. Accordingly, this research demonstrates a powerful role of shared leadership among followers, which is largely consistent with previous research on shared and distributed leadership (e.g., Gronn, 2002; Pearce \& Sims, 2002; Pearce et al., 2004). As such, our findings point to a need to include followers in leadership development efforts.

\subsection{Limitations}

As with all empirical research, there are some limitations to the present study that are worthy of mention. First, the design of the study does not allow us to infer direct causation. Although we have speculated about the existence of a causal relationship of vertical and shared leadership with new venture performance, it may in fact be the case that the respondents of high-performing firms simply attributed their success to the various forms of leadership studied in this research project, and responded accordingly. However, we believe that this potential threat may have been partly mitigated by the fact that our performance measures were acquired through secondary sources (i.e., Inc. Magazine and Dun and Bradstreet). Further, if such a bias truly existed on the part of the respondents, then we would not likely have identified a negative relationship of vertical transformational and empowering leadership with new venture performance. However, longitudinal research is of course required in order to verify our causal assumptions.

Also, although our response rates of $17.6 \%$ for study 1 and $33.5 \%$ for study 2 may appear relatively low, these percentages are in alignment with other research studies requesting the participation of top management (e.g., Neck, Meyer, Cohen, \& Corbett, 2004). Further, as previously reported, we conducted extensive tests of non-response bias on multiple variables for each study (e.g., firm age, revenue, growth rate) and found no significant differences to exist on any of these dimensions. However, the possibility exists that there were significant differences on other dimensions that we were not able to evaluate. In such case, the generalizability of the results may be limited. Nonetheless, generalizability is not our main concern. Rather, we are most interested in the importance of leadership dynamics within the context of new venture top management teams.

\section{Conclusion}

It has become increasingly clear in recent years that the conceptualization of leadership must be broadened beyond that of top-down heroic leadership (Day et al., 2004; Pearce, 2004; Yukl, 2002). As has been empirically demonstrated in the current article, shared leadership processes add substantial insight into the performance of organizations. Further, shared leadership appears to be particularly important in the development and growth of new ventures. Within this context, the explanatory value of shared leadership goes above and beyond that of vertical leadership. This suggests that high profile cases of prodigal entrepreneurs, whose individual creativity and charisma have led them to fame and fortune, are more myth than reality. If nothing else, the leadership of the principal founder is only part of the story behind most successful startups. It takes the leadership of an array of talented individuals to develop and grow new ventures. This highlights the great importance in selecting and developing top management teams, rather than simply attracting a superstar CEO: It is time to move beyond the moribund myth of the heroic entrepreneur as the sole leader of the firm. 


\section{References}

Amason, 1996 - A. C. Amason, Distinguishing the effects of functional and dysfunctional conflict on strategic decision making: Resolving a paradox for top management teams. Academy of Management Journal, 39:1 (1996), pp. 123-148.

Avolio et al., 1996 • B. J. Avolio, D. Jung, W. Murry, and N. Sivasubramaniam, Building highly developed teams: Focusing on shared leadership process, efficacy, trust, and performance; in: D. A. Beyerlein, D. A. Johnson, and S. T. Beyerlein, editors, Advances in Interdisciplinary Studies of Work Teams, JAI Press, Greenwich, CT (1996), pp. 173-209.

Baglia \& Hunt, 1988 • B. R. Baglia and J. G. Hunt, An organizational life cycle approach to leadership; in: J. G. Hunt, B. R. Baliga, H. P. Dachler, and C. A. Schriesheim, editors, Emerging Leadership Vistas, Lexington Books, Lexington, MA (1988).

Ball, 1991 - G. A. Ball, Outcomes of punishment incidents: The role of subordinate perceptions, individual differences, and leader behavior. PhD dissertation, Pennsylvania State University, University Park (1991).

Balogun \& Johnson, 2004 • J. Balogun and G. Johnson, Organizational restructuring and middle manager sensemaking. Academy of Management Journal, 47:4 (2004), pp. 523-549.

Baron, 2002 - R. A. Baron, Entrepreneurship and organizational behavior; in: B. M. Staw and R. Kramer, editors, Research in Organizational Behavior, Vol. 24, JAI Press, Greenwich, CT (2002), pp. 225-270.

Barry, 1991 - D. Barry, Managing the bossless team: Lessons in distributed leadership. Organizational Dynamics, 20:1 (1991), pp. 31-47.

Bass, 1985 - B. M. Bass, Leadership and Performance beyond Expectation, Free Press, New York (1985).

Baum et al., 1998 - J. R. Baum, E. A. Locke, and S. A. Kirkpatrick, A longitudinal study of the relation of vision and vision communication to venture growth in entrepreneurial firms. Journal of Applied Psychology, 83:1 (1998), pp. 43-54.

Brush \& Vanderwerf, 1992 - C. G. Brush and P. A. Vanderwerf, A comparison of methods and sources for obtaining estimates of new venture performance. Journal of Business Venturing, 7 (1992), pp. 157-170.

Bryant, 2004 - T. A. Bryant, Entrepreneurship; in: G. R. Goethals, G. J. Sorenson, and J. M. Burns, editors, Encyclopedia of leadership, Vol. 1, Sage, Thousand Oaks, CA (2004), pp. 442-448.

Burke et al., 2003 - C. S. Burke, S. Fiore and E. Salas, The role of shared cognition in enabling shared leadership and team adaptability; in: C. L. Pearce and J. A. Conger, editors, Shared Leadership: Reframing the Hows and Whys of Leadership, Sage, Thousand Oaks, CA (2003).

Burke, 1978 - J. Burke, Connections, Little Brown, Boston, MA (1978).

Burns, 1978 • J. M. Burns, Leadership, Harper \& Row, New York (1978).

Bygrave \& Minniti, 2000 • W. Bygrave and M. Minniti, The social dynamics of entrepreneurship. Entrepreneurship Theory and Practice, 24:3 (2000), pp. 25-36.

Cogliser \& Brigham, 2004 - C. C. Cogliser and K. H. Brigham, The intersection of leadership and entrepreneurship: Mutual lessons to be learned. Leadership Quarterly, 15 (2004), pp. 771-799.

Conger, 1999 - J. A. Conger, Charismatic and transformational leadership in organizations: An insider's perspective on these developing streams of research. Leadership Quarterly, 10:2 (1999), pp. 145-179.

Covin \& Slevin, 2002 • J. G. Covin and D. P. Slevin, The entrepreneurial imperatives of strategic leadership; in: M. A. Hitt, R. D. Ireland, S. M. Camp, and D. L. Sexton, editors, Strategic Entrepreneurship, Blackwell Publishers, Oxford (2002), pp. 309-327.

Covin \& Slevin, 2004 • J. G. Covin and D. P. Slevin, The concept of entrepreneurial leadership; in: M. A. Hitt and R. D. Ireland, editors, Entrepreneurship Encyclopedia, Blackwell Publishing, Malden, MA (2004).

Cox, 1994 - J. F. Cox, The effects of superleadership training on leader behavior, subordinate self-leadership behavior, and subordinate citizenship. PhD dissertation. University of Maryland, College Park (1994).

Cox et al., 2003 - J. F. Cox, C. L. Pearce, and H. P. Sims, Toward a broader agenda for leadership development: Extending the traditional transactional-transformational duality by developing directive, empowering and shared leadership skills; in: S. E. Murphy and R. E. Riggio, editors, The Future of Leadership Development, Lawrence Earlbaum, Mahwah, NJ (2003), pp. 161-180.

Day, 2000 • D. V. Day, Leadership development: A review in context. Leadership Quarterly, 11 (2000), pp. 581-613.

Day et al., 2004 • D. V. Day, P. Gronn and E. Salas, Leadership capacity in teams. Leadership Quarterly, 15:6 (2004), pp. 857-880.

Dean et al., 1998 - T. J. Dean, R. L. Brown, and C. E. Bamford, Differences in large and small firm responses to environmental context: Strategic implications from a comparative analysis of business formations. Strategic Management Journal, 19:8 (1998), pp. 709-728.

Dunphy \& Stace, 1993 •D. Dunphy and D. Stace, The strategic management of corporate change. Human Relations, 46:8 (1993), pp. 905-920.

Ensley et al., 2000 - M. D. Ensley, J. W. Carland, and J. C. Carland, Investigating the existence of the lead entrepreneur. Journal of Small Business Management, 38:4 (2000), pp. 59-77.

Ensley \& Pearce, 2001 - M. D. Ensley and C. L. Pearce, Shared cognition in top management teams: Implications for new venture performance. Journal of Organizational Behavior, 22:2 (2001), pp. 145-160.

Ensley et al., in press - M. D. Ensley, C. L. Pearce, \& K. M. Hmieleski (in press). Environmental dynamism: A moderator of the entrepreneur leadership behavior-new venture performance linkage. Journal of Business Venturing.

Ensley et al., 2003 • M. D. Ensley, A. Pearson, and C. L. Pearce, Top management team process, shared leadership, and new venture performance: A theoretical model and research agenda. Human Resource Management Review, 13:2 (2003), pp. 329-346.

Follett, 1924 - M. P. Follett, Creative Experience, Logmans Green, New York (1924).

Forsyth, 1999 • D. R. Forsyth, Group Dynamics, (3rd ed.), Brooks/Cole, Pacific Grove, CA (1999).

Gartner, 1989 - W. B. Gartner, Some suggestions for research on entrepreneurial traits and characteristics. Entrepreneurship Theory and Practice, 14:1 (1989), pp. 27-37. 
Gerstner \& Day, 1997 - C. Gerstner and D. Day, Meta-analytic review of leader-member exchange theory: Correlates and construct issues. Journal of Applied Psychology, 82:6 (1997), pp. 827-844.

Gilbreth \& Gilbreth, 1924 • F. B. Gilbreth and L. M. Gilbreth, Classifying the elements of work. Management and Administration, 8:2 (1924), pp. 151-154.

Greenleaf, 1977 • R. K. Greenleaf, Servant Leadership: A Journey into the Nature of Legitimate Power and Greatness, Paulist Press, New York (1977).

Gronn, 1999 • P. Gronn, Substituting for leadership: The neglected role of the leadership couple. Leadership Quarterly, 10:1 (1999), pp. 41-62.

Gronn, 2002 - P. Gronn, Distributed leadership as a unit of analysis. Leadership Quarterly, 13 (2002), pp. 423-451.

Gronn, 2005 • P. Gronn, Distributed Organizational Leadership, Information Age Publishing, Greenwich, CA (2005).

Gupta et al., 2004 • V. Gupta, I. C. MacMillan, and G. Surie, Entrepreneurial leadership: Developing and measuring a cross-cultural construct. Journal of Business Venturing, 19:2 (2004), pp. 241-260.

Hambrick \& Abrahamson, 1995 - D. C. Hambrick and E. Abrahamson, Assessing managerial discretion across industries: A multimethod approach. Academy of Management Journal, 38:5 (1995), pp. 1427-1441.

Hambrick \& Finkelstein, 1987 • D. C. Hambrick and S. Finkelstein, Managerial discretion: A bridge between polar views of organizational outcomes; in: B. M. Staw, and L. L. Cummings, editors, Research in Organizational Behavior, Vol. 9, JAI Press, Greenwich, CT (1987), pp. 369-406.

Hambrick \& Mason, 1984 - D. C. Hambrick and P. A. Mason, Upper echelons: The organization as a reflection of its top managers. Academy of Management Review, 9 (1984), pp. 193-206.

Hollenbeck et al., 1994 - J. R. Hollenbeck, D. R. Ilgen, and D. J. Sego, Repeated measures regression and mediational tests: Enhancing the power of leadership research. Leadership Quarterly, 5 (1994), pp. 3-23.

Hooker \& Csikszentmihalyai, 2003 - C. Hooker and C. Csikszentmihalyai, Flow, creativity and shared leadership: Rethinking the motivation and structuring of knowledge work; in: C. L. Pearce and J. A. Conger, editors, Shared Leadership: Reframing the Hows and Whys of Leadership, Sage, Thousand Oaks, CA (2003).

Ireland et al., 2003 - R. D. Ireland, M. A. Hitt, and D. G. Sirmon, A model of strategic entrepreneurship: The construct and its dimensions. Journal of Management, 29:6 (2003), pp. 963-989.

James et al., 1993 - L. R. James, R. G. Demaree, and G. Wolf, R/sub wg/: An assessment of within-group interrater agreement. Journal of Applied Psychology, 78:2 (1993), pp. 306-309.

Katzenbbach \& Smith, 1993 - J. R. Katzenbbach and D. K. Smith, The Wisdom of Teams, Harvard Business School Press, Cambridge, MA (1993).

Keats \& Hitt, 1988 • B. W. Keats and M. A. Hitt, A causal model of linkages among environmental dimensions, macro organizational characteristics, and performance. Academy of Management Journal, 31 (1988), pp. 570-598.

Kerr \& Jermier, 1978 - S. Kerr and J. Jermier, Substitutes for leadership: Their meaning and measurement. Organizational Behavior and Human Performance, 22 (1978), pp. 375-403.

Kets de Vries \& Miller, 1984 • M. F. R. Kets de Vries and D. Miller, The Neurotic Organization, Jossey-Bass, San Francisco (1984).

Kets de Vries \& Miller, 1986 • M. F. R. Kets de Vries and D. Miller, Personality, culture, and organization. Academy of Management Review, 11:2 (1986), pp. 266-279.

Kiefer \& Senge, 1999 - F. Kiefer and P. M. Senge, Metanoic organizations in the transition to a sustainable society. Reflections. The SoL Journal, 1:1 (1999), pp. 25-36.

Kuhn, 1970 • T. S. Kuhn, The Structure of Scientific Revolutions, University of Chicago Press, Chicago, IL (1970).

Lawler, 1986 • E. Lawler, High-Involvement Management: Participative Strategies for Improving Organizational Performance, Jossey-Bass, San Francisco (1986).

Manz \& Sims, 1984 • C. C. Manz and H. P. Sims, Searching for the "unleader": Organizational member views on leading self-managed groups. Human Relations, 37:5 (1984), pp. 409-424.

Manz \& Sims, 1987 - C. C. Manz and H. P. Sims, Leading workers to lead themselves: The external leadership of self-managing work teams. Administrative Science Quarterly, 32 (1987), pp. 106-128.

Manz \& Sims, 1993 - C. C. Manz and H. P. Sims, Businesses without Bosses: How Self-Managing Teams Are Building High Performance Companies, Wiley, New York (1993).

Marion \& Uhl-Bien, 2001 • R. Marion and M. Uhl-Bien, Leadership in complex organizations. Leadership Quarterly, 14:4 (2001), pp. $389-418$.

McGrath \& MacMillan, 2000 - R. McGrath and I. MacMillan, The Entrepreneurial Mindset, Harvard Business School Press, Cambridge, MA (2000).

McGregor, 1960 • D. McGregor, The Human Side of Enterprise, McGraw-Hill, New York (1960).

McGuire et al., 1986 - J. McGuire, T. Schneeweis, and J. Hill, An analysis of alternative measures of strategic performance; in: Advances in Strategic Management, JAI Press, New York (1986), pp. 124-156.

McKelvey, 2004 • B. McKelvey, Toward a complexity science of entrepreneurship. Journal of Business Venturing, 19:3 (2004), pp. 313-341.

Miller \& Friesen, 1984 •D. Miller and P. H. Friesen, A longitudinal study of the corporate life cycle. Management Science, 30:10 (1984), pp. 1161-1183.

Mischel, 1977 - W. Mischel, The interaction of person and situation; in: D. Magnusson and N. S. Endler, editors, Personality at the Crossroads: Current Issues in Interactional Psychology, Lawrence Erlbaum Associates, Hillsdale, NJ (1977), pp. 333-352.

Muczyk \& Reimann, 1987 • J. P. Muczyk and B. C. Reimann, The case for directive leadership. Academy of Management Executive, 1:4 (1987), pp. 301-311.

Mullins \& Cummings, 1999 - J. W. Mullins and L. L. Cummings, Situational strength a framework for understanding the role of individuals in initiating proactive strategic change. Journal of Organizational Change Management, 12:6 (1999), pp. 462-479. 
Neck et al., 2004 • H. M. Neck, G. D. Meyer, B. Cohen, and A. C. Corbett, An entrepreneurial system view of new venture creation. Journal of Small Business Management, 42:2 (2004), pp. 190-208.

Nicholls-Nixon, 2005 •C. L. Nicholls-Nixon, Rapid growth and high performance: The entrepreneur's “impossible dream?". Academy of Management Executive, 19:1 (2005), pp. 77-89.

Nunnally \& Bernstein, 1996 • J. C. Nunnally and I. H. Bernstein, Psychometric Theory, (3rd ed.), McGraw-Hill, New York (1996).

Pearce, 1997 - C. L. Pearce, The determinants of change management team effectiveness: A longitudinal investigation. PhD dissertation, University of Maryland, 1997.

Pearce, 2004 - C. L. Pearce, The future of leadership: Combining vertical and shared leadership to transform knowledge work. Academy of Management Executive, 18:1 (2004), pp. 47-57.

Pearce \& Conger, 2003 - C. L. Pearce and J. A. Conger, All those years ago: The historical underpinnings of shared leadership; in: C. L. Pearce and J. A. Conger, editors, Shared Leadership: Reframing the Hows and Whys of Leadership, Sage, Thousand Oaks, CA (2003), pp. 1-18.

Pearce \& Manz, 2005 - C. L. Pearce and C. C. Manz, The new silver bullets of leadership: The importance of self- and shared leadership in knowledge work. Organizational Dynamics, 34:2 (2005), pp. 130-140.

Pearce \& Sims, 2002 - C. L. Pearce and H. P. Sims, Vertical versus shared leadership as predictors of the effectiveness of change management teams: An examination of aversive, directive, transactional, transformational and empowering leader behaviors. Group Dynamics: Theory, Research, and Practice, 6:2 (2002), pp. 172-197.

Pearce et al., 2003 • C. L. Pearce, H. P. Sims, J. F. Cox, G. Ball, E. Schnell, and K. A. Smith, et al. Transactors, transformers and beyond: A multimethod development of a theoretical typology of leadership. Journal of Management Development, 22:4 (2003), pp. 273-307.

Pearce et al., 2004 - C. L. Pearce, Y. Yoo and M. Alavi, Leadership, social work and virtual teams: The relative influence of vertical versus shared leadership in the nonprofit sector; in: R. E. Riggio, S. Smith-Orr, and J. Shakely, editors, Improving Leadership in Nonprofit Organizations, Jossey-Bass, San Francisco, CA (2004), pp. 180-204.

Quinn \& Cameron, 1983 - R. E. Quinn and K. Cameron, Organizational life cycles and some shifting criteria of effectiveness: Some preliminary evidence. Management Science, 29:1 (1983), pp. 33-51.

Schein, 1997 • E. Schein, Organizational Culture and Leadership, Jossey-Bass, San Francisco, CA (1997).

Schriesheim et al., 1994 - C. A. Schriesheim, B. J. Tepper, and L. A. Tetrault, Least preferred co-worker score, situational control, and leadership effectiveness: A meta-analysis of contingency model performance predictions. Journal of Applied Psychology, 79:4 (1994), pp. 561-573.

Scully et al., 1994 • J. S. Scully, H. P. Sims, J. D. Olian, K. G. Smith, E. R. Schnell, and K. A. Smith, Tough times make tough bosses: A meso-analysis of CEO leader behavior. Leadership Quarterly, 5:1 (1994), pp. 59-83.

Shamir \& Lapidot, 2003 - B. Shamir and Y. Lapidot, Shared leadership in the management of group boundaries: A study of expulsions from officers' training courses; in: C. L. Pearce and J. A. Conger, editors, Shared Leadership: Reframing the Hows and Whys of Leadership, Sage, Thousand Oaks, CA (2003).

Smith et al., 1985 - K. G. Smith, T. R. Mitchell, and C. E. Summer, Top level management priorities in different stages of the organizational life cycle. Academy of Management Journal, 28:4 (1985), pp. 799-821.

Smith \& Miner, 1983 - N. R. Smith and J. B. Miner, Type of entrepreneur, type of firm, and managerial motivation: Implications for organizational life cycle theory. Strategic Management Journal, 4:4 (1983), pp. 325-340.

Stewart \& Barrick, 2000 - G. L. Stewart and M. R. Barrick, Team structure and performance: Assessing the mediating role of intrateam process and the moderating role of task type. Academy of Management Journal, 43:2 (2000), pp. 135-148.

Stinchcombe, 1965 - A. L. Stinchcombe, Social structures and organizations, J. G. March, editor, Handbook of Organizations, Rand McNally, Chicago, IL (1965), pp. 142-193.

Swezey \& Salas, 1992 • R. W. Swezey and E. Salas, Teams: Their Training and Performance, Ablex Publishing, Westport, CT (1992).

Taylor, $1911 \bullet$ F. W. Taylor, The Principles of Scientific Management, Harper \& Brothers, New York (1911).

Ucbasaran et al., 2003 - D. Ucbasaran, A. Lockett, M. Wright, and P. Westhead, Entrepreneurial founder teams: Factors associated with member entry and exit. Entrepreneurship Theory and Practice, 28:2 (2003), pp. 107-128.

Vecchio, 2003 - R. Vecchio, Entrepreneurship and leadership: Common trends and common threads. Human Resource Management Review, 132 (2003), pp. 303-327.

Vroom \& Yetton, 1973 • V. H. Vroom and P. W. Yetton, Leadership and Decision Making, University of Pittsburgh Press, Pittsburgh (1973).

Ward, 2004 - T. B. Ward, Cognition, creativity, and entrepreneurship. Journal of Business Venturing, 19 2 (2004), pp. 173-188.

Williamson, 2000 - I. O. Williamson, Employer legitimacy and recruitment success in small businesses. Entrepreneurship Theory and Practice, 25:1 (2000), pp. 27-42.

Winborg \& Landstrom, 2001 • J. Winborg and H. Landstrom, Financial bootstrapping in small businesses: Examining small business managers' resource acquisition behaviors. Journal of Business Venturing, 16:3 (2001), pp. 235-254.

Wolff et al., 2002 - S. B. Wolff, A. T. Pescosolido, and V. U. Druskat, Emotional intelligence as the basis of leadership emergence in self-managing teams. Leadership Quarterly, 13:5 (2002), pp. 505-522.

Yukl, 2002 • G. Yukl, Leadership in Organizations, Prentice Hall, Upper Saddle River, NJ (2002).

Zaccaro et al., 2001 - S. J. Zaccaro, A. L. Rittman, and M. A. Marks, Team leadership. Leadership Quarterly, 12 (2001), pp. 451-454. 